\title{
EMOTIONAL MATURITY AND INSECURITY AMONG SCHOOL TEACHERS
}

\author{
Rinku Mathews*
}

\section{INTRODUCTION}

\section{EMOTIONAL MATURITY:-}

\subsection{EMOTION:-}

Emotion is a state of special readiness for emergency action. It involves a changes in the activity of the organs a circulation digestion and so on. It also involves a change in mental activity and often a change in voluntary activity.

Emotion has many values in our lives. It gives us extra power in physical emergencies. It provides a drive, a forcing in to action that is often very worthwhile. Emotion gives quality and color to our living moreover, mild present emotion seems to be good for us physically.

Emotions, when strong, tend to disrupt our thinking. What is more, they are often a poor guide to action. We are apt to do something we shouldn't if we follow our emotions blindly. Emotions can make us slaves to other people. An unscrupulous person can rouse our emotions, connect the action and if we want with those emotions and we will do what we want rather than what our own good judgment night tell us to do.

\subsection{MATURITY:-}

The concept of maturity has not received a great deal of explicit attention in the literature. Delineation of libidinal development has been yielded the important formulation of the 'Genital level' and 'object-interest', recent emphasis on the conflict between the regressive, dependents, productive forces in the personality has directed interest toward the more detailed mature of maturity.

\subsection{NATURE OF MATURITY:-}

- One of the most obvious pathways of development, long emphasized by Sigmund Freud and Franz Alexander, is from the parasitic, dependence of the fetus to the relative independence, of parent, with parental capacity for spouse and child.

*M.A, Dept. of Psychology, SP University, V.V. Nagar

(c) www.ijip.in 
- Intimately bound-up with the organism's development from parasitism on the mother to relative independence from the parents is its increased capacity for responsibility and productivity and its decreased receptive needs Children learn to control their hostilities, their sexuality and other impulses, and to develop the orientations of maturity largely through the incentive of being loved.

- Third characteristic of maturity is relative freedom from the well-known constellation of inferiority, egotism and competitiveness.

- Another aspect of maturity consists in the conditioning and the training necessary for socialization and domestication.

- Hostile aggressiveness, using the term to include all sorts of anger, hate cruelty and belligerency, is always a sign of emotional irritation or threat.

- Another important attribute of maturity is a firm sense of reality.

- Another characteristic of maturity is flexibility and adaptability.

\subsection{EMOTIONAL MATURITY:-}

One outcome of healthy emotional development is increasing "emotional maturity should be regarded as relative, not final or absolute. The process of maturing emotionally is never complete for a person in fairly good health mentally continues to grow more "miller" in his attitude toward life and toward himself as long as he lives. When we say that a major aim of a good educational program is to help earners to gain in emotional maturity, what we mean is not the achievement of a certain and product that can be graded or rated on graduation day, but rather seeking to help the child in a process of development that continues long after most people leave school.

According to this view, the emotionally mature person is able to keep a lid on his feelings. He can suffer in silence .He can bide his time in spite of present discomfort. He is not subject to swing in mood, he is not volatile. When a person expresses his emotion he does it feelings. He should have considerable tolerance for frustration and so on.

"Mature" emotional behavior at any level of growth is that which most fully reflect the fruit of healthy development in all the interacting aspect of the person's development.

Emotional maturity present in an individual should take an account of the full scope of the individual power, capacity, and ability to use and enjoy them.

Emotional maturity means that the realized his potential for richness of living and has development has the capacity to enjoy thing, to relate himself to others, to live and to laugh or to show fear when there is occasion to be frightened.

(c) www.ijip.in 
Maturity is the stage attained by the process of growth and development and body change resulting from heredity rather than learning. The term maturity is used to describe behavioural or physical changes which emerge as the human grows older. It is still through by some psychologist that the development of much behavior may be maturational.

Maturity refers to the growth of an organism that is determined primarily by genetic factors and occurs more or less independently of learning.. These built in maturational processes provide the potentials for the orderly progression of development, but these potentials can be realized only under favorable environmental conditions. Although a person's a growth will be shaped in different ways in different cultures, certain characteristic trends can be seen in any society, primitive or advanced.

According to GESELL (1956), PIAGET (1970) there are 7 psychological conditions that foster healthy development to be wanted, to be born healthy, to live in a healthy environment, to satisfaction of basic needs, to continuous loving care, to appropriate treatment for psychological and behavioral problems and difficulties, to a acquire to intellectual, emotional and social skills necessary to cope effectively in our society.

In the present circumstances, children, youth, and adults all are facing problems and difficulties in life and work. These conditions are giving rise to several psychosomatic problems such as anxiety, tension, conflicts, pressures, frustrations, strains and stresses and emotional upsets and disturbances, so the study of emotional development deals with interplay of biological, psychosocial and socio-cultural forces. Actually, emotional maturity is not only the effective determinant of personality but it also helps to control the growth and development of the person. The concept 'mature emotional behavior' at any stage of development reflects the fruits of normal emotional development.

* Controlling our emotions: Emotional maturity is, first of all, being in control of our emotions -having our reason give approval for our action rather than having only an emotional backing for it. Poise is an accompaniment of emotional maturity. The poised person is the one who is always in control of his emotion. No awkward situation brings him embarrassment. He is never overeager, ever effusive, overmodest. Most of us, when thrown publicly in to a situation which we don't know how to meet at the moment are apt to respond to it with some sort of emotional disruption, often with that of embarrassment. The poised person in contrast, has had enough variety in his experiences to learn to hang on to himself emotionally no matter what confronts him, no matter what demands are made on him.

* Making proper use of our emotions: Emotional maturity is , in the secondly place, making proper use of our emotions as the basis for action. It is true that mild emotion

(C) www.ijip.in 
does give an added sense of well-being and for reason there is some justice in allowing the mild pleasant emotions to suffuse us just for the pleasure they give us in themselves. Such emotions are conductive to good health. Generally speaking, however, our emotional energy should not be the kind that burns and turns to ashes, but it should rather be the kind that burns and flows in to action. In the emotionally immature person, emotion too often gives just heat and not energy. Such a person may be filled with sympathy for the slum dwellers in his city, but he won't use that energy for actin. He may be highly indignant over corruption in politics, but his emotions while burn without giving any value.

* Being aware of our emotions: Emotional maturity is, in the third place being conscious of whether of not we are acting on the basis of emotion or thought of feeling or thinking. We may be depressed and discouraged and life may look hopeless to us: Yet, if we can be aware that it is emotion which is giving our whole situation its unpleasant tone and if we can then look at the facts realistically, we may find much that is comforting and encouraging. We may accept every idea that a radio commentator sets forth; yet, if we study the reasons for this acceptance, we may find that we have given him an emotional allegiance which has put us in a highly receptive mood. If we divorce our thinking from that emotion, we may find many of his idles unacceptable the light of our intelligence. We may say about something difficult: 'I can't do it: It may be only fear of the unknown that is speaking. If we recognize the emotion and discount it, we can see the situation, more clearly and we may find that it is something we can do with no great trouble. We may vote in class election with a sense of having made our choice with good judgment. In reality we may be acting only as our feelings of linking and disliking dictate and without any great intelligence at all. We should be aware of this fact so that we can do better the next time. It is highly important that we always be aware of the part that emotion is playing in our allegiances, our actions, our judgments; for only when we known that, can we make sure that our divisions are intelligent and based on experience.

* Proper balance and fullness: Emotional maturity is, finally having the proper balance and fullness in our emotional life there are people who have an excess of emotion in one area or another. Some lavish it freely without judgment. They are as awe-stricken by an unusual magazine cover as by the Ground Canyon; they are as sympathetic towards a dog that is hungry as toward a child who is starving, they are as hurt by some one's failing to speak to them as by losing a learn friend. Some people let one emotion pervade all of their living one person is constantly filled with fear of one sort or another; one is excessively loyal toward her own family or her own friends; one is too quick to become angry; one is too easily depressed or too easily elated. 
In contrast, there are people who are afraid of emotion and use too little of it they get no thrill form any kind of music. They are not exhilarated by any kind of natural beauty. Such as sunrise, sunset, storm or sunshine, red maples in autumn, new green in spring etc. Everything, literally, leaves them cold. Perhaps most serious is the fact that they feel little warmth toward people and know little or the joy of giving and often of receiving affection.

Some people seem to be more emotional than others of course we cannot depend upon appearances always, because convention decrees that we keep a calm and unruffled exterior no matter what is boiling up inside. Still it is true that, as with all human traits, we find all variations in emotionality, from the cold person who varies seldom departs from his ordinary calm to the person who is always reacting to everything with a rush of feeling.

\section{INSECURITY:-}

Insecurity is characterized by the loss of emotional stability or self-confidence. Suffers perceive themselves to be unloved, inadequate or lacking self-worth. Insecurity can lead to psychological problem or over-compensatory behavior such as bulling or aggression.

Insecurity is a feeling of general unease or nervousness that may be triggered by perceiving of oneself to be vulnerable in some way or a sense of vulnerability or harm or instability which threaten one's self-image or ego.

A person suffering from insecurity from insecurity lacks confidence in their own value, and one or more of their capabilities, lacks trust in them or has fears that a present positive state is temporary and which will let them down and cause them loss by going wrong in the future. This is a common trait which only differs in the people's degree.

Insecurity is not objective evaluation of one's ability but an emotional interpretation is when two people with the same capacities may have entirely different level of insecurity. There are many factor which contribute to the development of insecurity like shyness, paranoia and social withdrawal and in some cases it may lead to compensatory behaviors such as arrogance, regressions or bulling.

It is a true fact that the majorities of the human beings are emotional and have rhe capacity to be hurt, but emotional insecurity could merely be a difference in awareness. Insecurity affect the several levels of it which nearly causes some degree of isolation to an insecure person who always try to withdraw from other people to some extent.

The greater the insecurity, the higher the degree of isolation becomes. The insecurity is is often rooted in a person's childhood years. As insecurity can often be accompanied by a controlling personality type or avoidance as psychological defense mechanism.

(C) www.ijip.in 
Insecurity can be overcome but it takes time, patience and a gradual realization that one's own worth is purely a matter of perspective. While insecurity follows from concerns relating to objective reality and this is not a necessity, but more a tendency.

\subsection{CAUSES OF INSECURITY:-}

Insecurity affects people in a number of ways either during specific situations or in everyday life. Some people find that in the workplace they feel secure but in social situations they feel uncomfortable. In some cases, insecurity can completely cripple an individual leading to low self-worth.

Some insecurity is natural and can act as a warning sign when faced with risky situations. Severe insecurity is often the result of a traumatic experience, abuse or neglect during childhood. Some people become insecure after a bereavement or loss. The overriding cause of insecurity is typically due to low self-esteem. Strong feelings of fear about everyday situations and activities can be extremely limiting causing a vicious cycle that is difficult to break.

\subsection{Five causes of insecurity:}

- Continual sense of not being accepted. When we grow up thinking no one truly likes us, lack of confidence and shyness can easily develop and carry on into adulthood.

- Personal tragedy such as a broken home, the sudden death of a close family member or a job loss can trigger this feeling.

- Poor reflection of the physical body. Self esteem can be damaged due to body shape, weight, hair loss, skin marks, height or other physical traits. A sense of shame and selfconsciousness can infiltrate daily life.

- Feeling less important in comparison to others. For example, comparing intelligence, looks, wealth, achievements, education, or anything else that could create self-doubt.

- A Failure-in-Life attitude. A severe setback in a personal relationship, career, or health could have devastating effects to someone's self image.

\subsection{Signs of Insecurity}

Security is something, which is desired by everyone. That is why it is important for all of us to be comfortable with ourselves. A secure person is more likely to achieve success, have meaningful relationships and be respected by others. On the contrary, insecure people find it very difficult to manage things in every aspect of their lives. Though it is impossible to be completely free of doubt, one should try to be confident of himself. For this, keep checking yourself to eliminate any signs of insecurity that might creep in. if you want to know what are signs of an insecure person, read on.

\subsection{Signs of Insecure person}

(c) www.ijip.in 
- An insecure person becomes overly selfish. He tries to surround himself with possessions, accolades and attention.

- An insecure person becomes overly accommodating and tries to gain other people's approval.

- Insecure people tend to be very defensive and cannot handle criticism. They are not comfortable with their own-self.

- Insecure people can't enjoy silence and they try to fill it with unnecessary chatter.

- Excessive joking is also a mechanism for coping with insecurity. An insecure person craves for other people's attention, which is achieved when other people laugh at their jokes. However, this leads to insensitivity towards others.

- Insecure people are self promoting and constantly talk about themselves. They need validation from other people for their actions and qualities.

- Insecure people are even threatened by others and therefore by bullying they try to crush their opinion.

- Insecure people tend to be overly authoritative as they tend to compensate for their lack of confidence by taking out their frustrations on their subordinates.

- Over competitiveness is also a sign of insecurity. They are scared of losing and so they always keep themselves at the edge.

- Being materialistic also shows that person is insecure because he feels that by acquiring material wealth and showing it off he will be able to gain people's attention and acknowledgement.

- Over jealousy is yet another sign of insecure people as they lack trust in their partners. This is visible in constant questioning, mistrust and altercations with the members of the opposite sex.

- Insecure people even become abusive if they fail to control their partners.

- Overly sexual behavior also portrays insecurity as the person treats his or her sexuality as a crutch to get other's attention.

\subsection{Symptoms of insecurity}

Insecurity can have a variety of associated symptoms which are usually signs of other conditions such as anxiety. Symptoms can be physical, emotional and psychological and may 
include:

- Self-doubt

- Indecisiveness

- Obsessing

- Low self-esteem

- Fear

- Jealousy

- Increased heart rate

- Dependency

- Being defensive

- Materialistic

- Overly authoritative

- Overly competitive

2.6 Negative effect of an insecure people:-

Have difficulties in establishing healthy, long-lasting relationships.

- Be perceived incorrectly by others as being snobbish or uppity

- Become victims of fears that impair their freedom of action or choice.

- Be candidates for paranoia feeling others are out to get them.

- Scare others away from them by their defensive attitude.

- Be over-controlled emotionally, having problems letting others in on their emotions.

- This can lead others to guess what is going on until the passivity of the insecure person leads to an over-reaction by the others, resulting in conflict or rejection.

- Have problems on the job or in school when they have the knowledge, skills and abilities to do a task efficiently but are told to do it in a different, less effective manner.

- They get so uptight about the job and are fearful of standing up for what they believe that they get angry, hostile and resentful until they either quit or succeed in submerging their emotions.

- Get passed over for promotions, advances or honors because they are so quiet about what it is they do. This leads the insecure persons to feel more unaccepted, unappreciated and under-valued.

- Have problems meeting people and often can become debilitated socially by chronic shyness.

- Become so inward that they seek to escape into their fantasy life rather than deal with the reality of their lives.

\subsection{PROBLEM STATEMENT:-}

"A study of emotional maturity and insecurity among teachers of schools."

(C) www.ijip.in 


\subsection{OBJECTIVES OF THE STUDY:-}

- To study the emotional maturity and insecurity of school teachers.

- To study the emotional maturity and insecurity of fix payment teachers.

- To study the emotional maturity and insecurity of permanent payment teachers.

- To study the emotional maturity and insecurity of male fix payment teacher.

- To study the emotional maturity and insecurity of male permanent payment teacher.

- To study the emotional maturity and insecurity female fix payment teacher.

- To study the emotional maturity and insecurity female permanent payment teacher.

\subsection{VARIABLES:-}

I. INDEPENDENT VARIABLE:-

A. SEX

A1 male

A2 female.

B. Pay

B1 fix payment

B2 permanent payment.

II. DEPENDENT VARIABLE:-

1. Emotional maturity

2. Insecurity.

III. CONTROL VARIABLE:-

School teachers of v.v.nagar, anand.

\subsection{HYPOTHESIS:-}

It is a fact that hypothesis in any research work is very important without hypothesis researches would go astray:-

- There will be no significant difference between male and female in emotional maturity.

- There will be no significant difference between male and female in emotional un-stability.

(c) www.ijip.in 
- There will be no significant difference between male and female in emotional regression.

- There will be no significant difference between male and female in social maladjustment.

- There will be no significant difference between male and female in personality disintegration.

- There will be no significant difference between male and female in lack of 5 independence.

- There will be no significant difference between male and female in insecurity.

- There will be no significant difference between male and female in insecurity un-stability.

- There will be no significant difference between male and female in insecurity regression.

- There will be no significant difference between male and female in social maladjustment.

- There will be no significant difference between male and female in personality disintegration.

- There will be no significant difference between male and female in lack of independence.

3.6 SAMPLE:-

The sample will be of 100 different schools from v.v.nagar, Anand.

V\&C Patel school, T.V Patel school, I.B. Patel school.

\subsection{RESEARCH DESIGN:-}

This research will be adopted $2 \times 2$ factorial design

\begin{tabular}{|l|l|l|l|}
\hline & MALE(A1) & FEMALE(A2) & TOTAL \\
\hline FIX(B1) & 25 & 25 & 50 \\
\hline PERMANENT(B2) & 25 & 25 & 50 \\
\hline TOTAL & & & 100 \\
\hline
\end{tabular}

3.8 Tools:-

INSECURITY QUESTIONNAIRE BY DR.G.C.PATI, MENTAL HEALTH INSTITUTE, SCB MEDICAL COLLEGE, CUTTACK

(c) www.ijip.in 
(ORISSA). EMOTIONAL MATURITY QUESTIONNAIRE BY DR. YASHVIR SINGH AND DR. MAHESH BHARGAVA.

\section{INSECURITY:-}

INS QUESTIONNAIRE constructed and standardized by DR. G.C Pati, mental health institute, SCB Medical college, Cuttack (ORISSA) .The score of insecurity is when a person put a tick mark $(\sqrt{ })$ on "yes", then the score will be 0 . And when a person put a cross mark $(\times)$ on "no", then the score will be 1respectively. The validity co-efficient $\mathrm{R}=.717$ and a high test retest reliability (reliability co-efficient $r=.92$ respectively.

\section{EMOTIONAL MATURITY}

Table no 1.1: Showing the result of mean difference in fixed payment in respect to Emotional un-stability.

A1-A2 1

t-Test: Paired Two Sample for Means

\begin{tabular}{lll}
\hline & Variable & Variable \\
& 1 & 2 \\
\hline Mean & 21.06 & 19.46 \\
Variance & 28.22082 & 27.80449 \\
Observations & 50 & 50 \\
Pearson Correlation & -0.18096 & \\
Hypothesized Mean Difference & 0 & \\
df & 49 & \\
t Stat & 1.390902 & \\
P $(\mathrm{T}<=\mathrm{t})$ one-tail & 0.08527 & \\
t Critical one-tail & 1.676551 & \\
$\mathrm{P}(\mathrm{T}<=\mathrm{t})$ two-tail & 0.170539 & \\
$\mathrm{t}$ Critical two-tail & 2.009575 & \\
\hline
\end{tabular}

Table No 1.1.1: Showing the mean difference in fixed payment in respect to Emotional un-stability.

\begin{tabular}{|l|l|l|l|l|}
\hline Groups & Mean & SD & df & t-value \\
\hline Male (A1) & 21.06 & 5.31 & 49 & 1.390902 \\
\cline { 1 - 3 } Female (A2) & 19.46 & 5.28 & & \\
\hline
\end{tabular}

The $t$ value is 1.390902. As shown in the table the mean of groups male (A1) is 21.06 and female (A2) are19.46. There is no significant difference between male and female in emotional maturity. Therefore the hypothesis stating "There will be no significant difference in the level

(C) www.ijip.in 
of fixed payment in respect to Emotional un-stability in between male and female is accepted. Here mean of (A1)is little bit higher than mean of (A2).

Chat No 1.1.1: Showing the mean difference in fixed payment in respect to Emotional unstability.

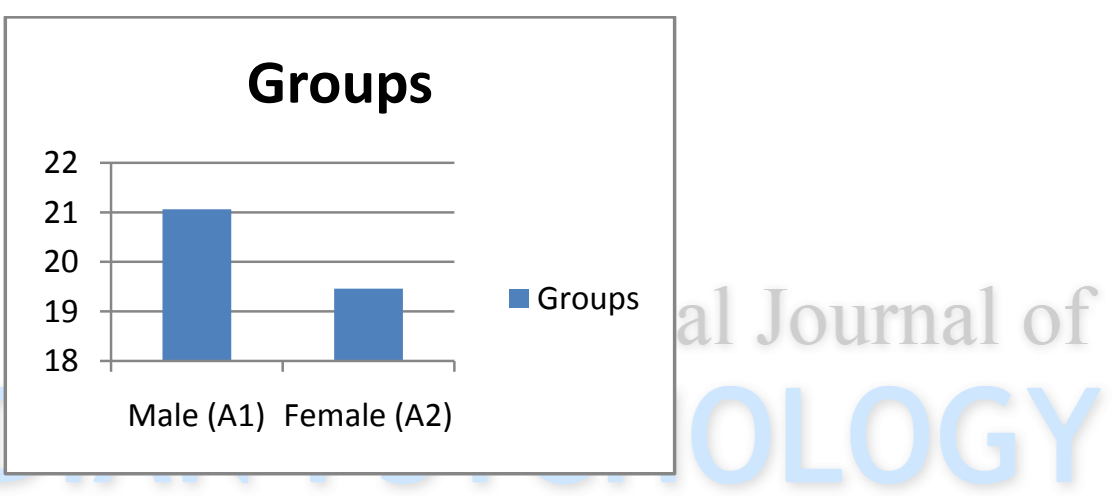

Table no 1.2: Showing the result of mean difference in fixed payment in respect to emotional regression

t-Test: Paired Two Sample for Means

\begin{tabular}{lll}
\hline & Variable & Variable \\
& 1 & 2 \\
\hline Mean & 20.12 & 18.1 \\
Variance & 65.12816 & 38.90816 \\
Observations & 50 & 50 \\
Pearson Correlation & 0.028947 & \\
Hypothesized Mean Difference & 0 & \\
df & 49 & \\
t Stat & 1.420409 & \\
P(T<=t) one-tail & 0.08091 & \\
t Critical one-tail & 1.676551 & \\
& & \\
& &
\end{tabular}



$\mathrm{P}(\mathrm{T}<=\mathrm{t})$ two-tail
0.161821
t Critical two-tail
2.009575

Table No:1.1.2 Showing the mean difference in fixed payment in respect to emotional regression

\begin{tabular}{|l|l|l|l|l|}
\hline Groups & Mean & SD & df & t-value \\
\hline Male (A1) & 20.12 & 8.07 & 49 & 1.420409 \\
\cline { 1 - 3 } Female (A2) & 18.1 & 6.24 & & \\
\hline
\end{tabular}

The $\mathrm{t}$ value is 1.420409. As shown in the table the mean of groupsmale(A1) is 21.12 and female (A2) is 18.1.There is no significant difference between male and female in fixed payment in respect to emotional regression. Therefore the hypothesis stating "There will be no significant difference in the level of fixed payment in respect to emotional regression in between male and female is accepted. Here mean of (A1) is little bit higher than mean of (A2).

Chat No 1.1.2: Showing the mean difference in fixed payment in respect to emotional regression.

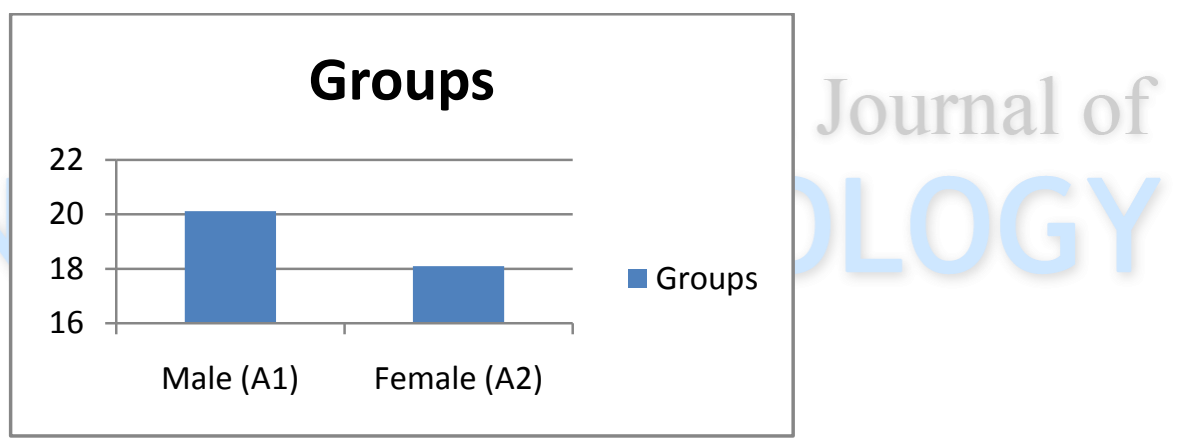

Table no 1.3: Showing the result of mean difference in fixed payment in respect to social maladjustment

t-Test: Paired Two Sample for Means

\begin{tabular}{lll}
\hline & Variable & Variable \\
& 1 & 2 \\
\hline Mean & 21.78 & 19 \\
Variance & 39.11388 & 26.61224 \\
Observations & 50 & 50 \\
Pearson Correlation & -0.17838 & \\
Hypothesized Mean Difference & 0 & \\
df & 49 & \\
t Stat & 2.236758 \\
P(T<=t) one-tail & 0.014943 & \\
& \multicolumn{2}{c}{13} \\
C www.ijip.in & &
\end{tabular}


t Critical one-tail $\mathrm{P}(\mathrm{T}<=\mathrm{t})$ two-tail t Critical two-tail
1.676551

0.029886

2.009575

Table No:1.1.3 showing the mean difference in fixed payment in respect to social maladjustment

\begin{tabular}{|l|l|l|l|l|}
\hline Groups & Mean & SD & df & t-value \\
\hline Male (A1) & 21.78 & 6.25 & 49 & 2.236750 \\
\cline { 1 - 3 } Female (A2) & 19 & 5.16 & & \\
\hline
\end{tabular}

The t- value is 2.236750. As shown in the table the mean of group's male (A1) is 21.78 and female (A2) is 19.There is no significant difference between male and female in social maladjustment.therefore the hypothesis stating "There will be no significant difference in the level of fixed payment in respect to social maladjustmentin between male and female is accepted. Here mean of (A1) is little bit higher than mean of (A2).

Chat No 1.1.3: Showing the mean difference in fixed payment in respect to social maladjustment.

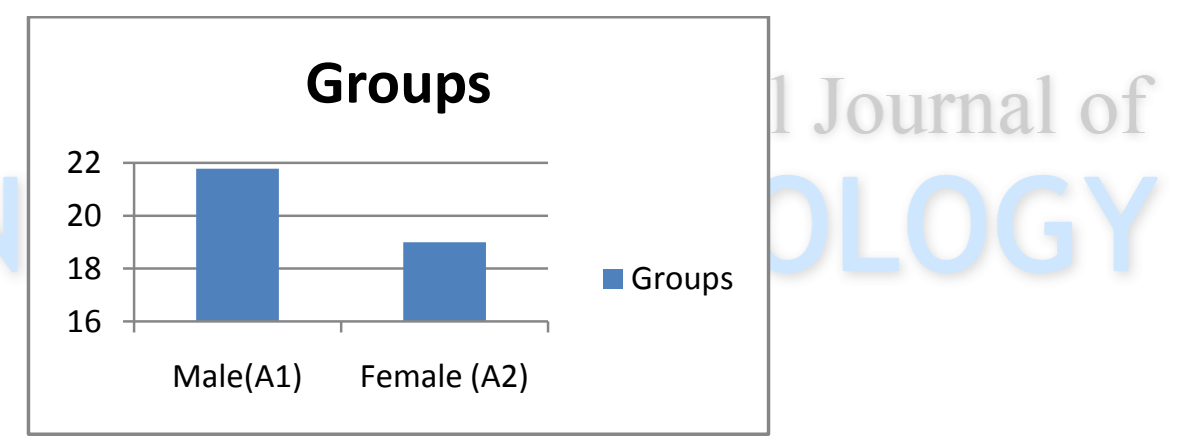

Table No:1.1.4showing the result of means difference in fixed payment in respect to personality disintegration.

A1-A2 4

t-Test: Paired Two Sample for Means

\begin{tabular}{lll}
\hline & Variable & Variable \\
& 1 & 2 \\
\hline Mean & 18.8 & 17.14 \\
Variance & 39.7551 & 35.79633 \\
Observations & 50 & 50 \\
Pearson Correlation & -0.06092 & \\
& 14 & \\
C www.ijip.in & &
\end{tabular}




\begin{tabular}{ll} 
Hypothesized Mean Difference & 0 \\
df & 49 \\
t Stat & 1.311138 \\
P $(\mathrm{T}<=t)$ one-tail & 0.097961 \\
t Critical one-tail & 1.676551 \\
P $(\mathrm{T}<=t)$ two-tail & 0.195922 \\
t Critical two-tail & 2.009575 \\
\hline
\end{tabular}

Table No:1.1.4showing the mean difference in fixed payment in respect to personality disintegration.

\begin{tabular}{|l|l|l|l|l|}
\hline Groups & Mean & SD & df & t-value \\
\hline Male (A1) & 18.8 & 6.31 & 49 & 1.311138 \\
\cline { 1 - 3 } Female (A2) & 17.14 & 5.98 & & \\
\hline
\end{tabular}

The $\mathrm{t}$ - value is 1.311138. As shown in the table the mean of group's male (A1) is 18.8 and female (A2) is 17.14.There is no significant difference between male and female in personality disintegration. Therefore the hypothesis stating "There will be no significant difference in the level of fixed payment in respect to personality disintegration in between male and female is accepted. Here mean of (A1) is little bit higher than mean of (A2).

Chat No 1.1.4: Showing the mean difference in fixed payment in respect to personality disintegration.

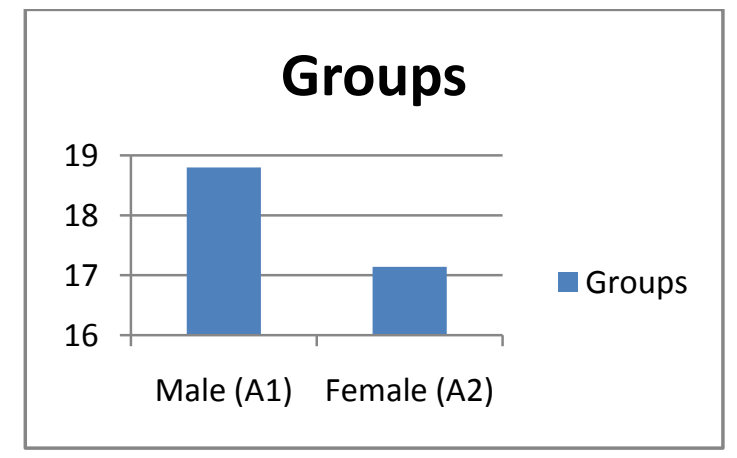

Table No: 1.1.5 showing the result of mean difference in fixed payment in respect to lack of independence.

(c) www.ijip.in 
A1-A2 5

\begin{tabular}{lll}
\hline & Variable & Variable \\
& 1 & 2 \\
\hline Mean & 17.18 & 16.54 \\
Variance & 27.3751 & 27.68204 \\
Observations & 50 & 50 \\
Pearson Correlation & -0.0555 & \\
Hypothesized Mean Difference & 0 & \\
df & 49 & \\
t Stat & 0.593649 & \\
$\mathrm{P}(\mathrm{T}<=\mathrm{t})$ one-tail & 0.277739 & \\
t Critical one-tail & 1.676551 & \\
$\mathrm{P}(\mathrm{T}<=\mathrm{t})$ two-tail & 0.555478 & \\
$\mathrm{t}$ Critical two-tail & 2.009575 & \\
\hline
\end{tabular}

Table No:1.1.5showing the mean difference in fixed payment in respect to lack of independence.

\begin{tabular}{|l|l|l|l|l|}
\hline Groups & Mean & SD & df & t-value \\
\hline Male (A1) & 17.18 & 5.19 & 49 & 0.593649 \\
\cline { 1 - 3 } Female (A2) & 16.54 & 5.17 & & \\
\hline
\end{tabular}

The t- value is 0.593649 . As shown in the table the mean of group's male (A1) is 17.18 and female (A2) is 16.54.There isno significant difference between male and female in fixed payment in respect to lack of independence. Therefore the hypothesis stating "There will be no significant difference in the level of fixed payment in respect to lack of independence in between male and female is accepted. Here mean of (A1) is little bit higher than mean of (A2).

Chat No 1.1.5: Showing the mean difference in fixed payment in respect to lack of independence.

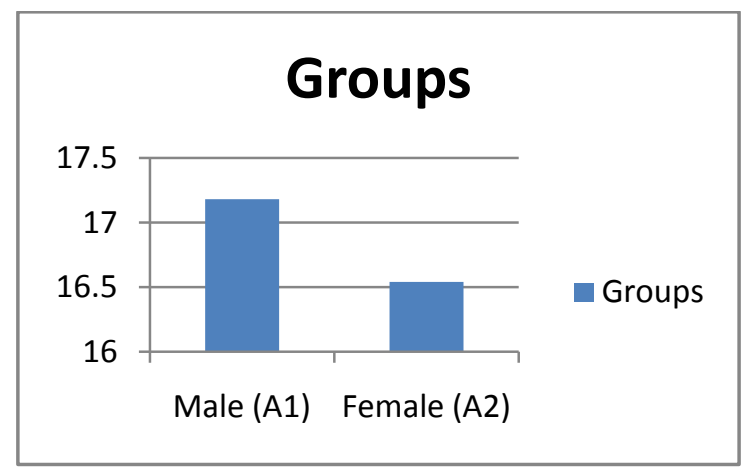

Table No:1.1.6 showing the result of mean difference in fixed payment in respect to Emotional maturity.

(c) www.ijip.in 
A1-A2 6

\begin{tabular}{lll}
\hline & Variable & Variable \\
& 1 & 2 \\
\hline Mean & 98.94 & 90.24 \\
Variance & 682.0167 & 510.0637 \\
Observations & 50 & 50 \\
Pearson Correlation & -0.08323 & \\
Hypothesized Mean Difference & 0 & \\
df & 49 & \\
t Stat & 1.712641 \\
$\mathrm{P}(\mathrm{T}<=\mathrm{t})$ one-tail & 0.04655 & \\
$\mathrm{t}$ Critical one-tail & 1.676551 \\
$\mathrm{P}(\mathrm{T}<=\mathrm{t})$ two-tail & 0.093101 & \\
$\mathrm{t}$ Critical two-tail & 2.009575 & \\
\hline
\end{tabular}

Table No 1.1.6: Showing the mean difference in fixed payment in respect to Emotional maturity.

\begin{tabular}{|l|l|l|l|l|}
\hline Groups & Mean & SD & df & t-value \\
\hline Male (A1) & 98.94 & 26.35 & 49 & 1.712641 \\
\cline { 1 - 3 } Female(A2) & 90.24 & 22.42 & & \\
\hline
\end{tabular}

The t- value is 1.712641. As shown in the table the mean group'smale (A1) is 98.94 and female (A2) is 90.24. There is significant difference between male and female in Emotional maturity. Therefore the hypothesis stating "There will be no significant difference in the level of fixed payment in respect to lack of independence in between male and female is accepted. Here the mean of (A1) is little bit higher than mean of (A2).

Chat No 1.1.6: Showing the mean difference in fixed payment in respect to Emotional maturity.

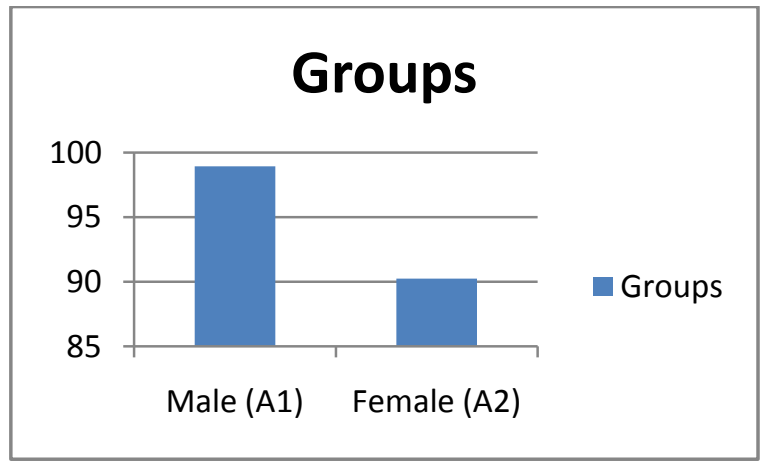

(c) www.ijip.in 
Table No: 1.1.7 showing the result of means difference in fixed payment in respect to Insecurity.

$$
\text { A1-A2 } 7
$$

\begin{tabular}{lll}
\hline & Variable & Variable \\
& 1 & 2 \\
\hline Mean & 6.46 & 5.66 \\
Variance & 7.069796 & 7.616735 \\
Observations & 50 & 50 \\
Pearson Correlation & 0.085713 & \\
Hypothesized Mean Difference & 0 & \\
df & 49 & \\
$\mathrm{t}$ Stat & 1.54369 & \\
$\mathrm{P}(\mathrm{T}<=\mathrm{t})$ one-tail & 0.064549 & \\
$\mathrm{t}$ Critical one-tail & 1.676551 & \\
$\mathrm{P}(\mathrm{T}<=\mathrm{t})$ two-tail & 0.129098 & \\
$\mathrm{t}$ Critical two-tail & 2.009575 \\
\hline
\end{tabular}

Table No: 1.1.7 showing the result of mean difference in fixed payment in respect to Insecurity.

\begin{tabular}{|l|l|l|l|l|}
\hline Groups & Mean & SD & df & t-value \\
\cline { 1 - 3 } Male (A1) & 6.46 & 2.68 & 49 & 1.54369 \\
\cline { 1 - 3 } Female (A2) & 5.66 & 2.76 & & \\
\hline
\end{tabular}

The t- value is 1.54369. As shown in the table the mean group'smale (A1) is 6.46 and female (A2) is 5.66.There is no significant difference between male and female in Insecurity. Therefore the hypothesis stating "There will be no significant difference in the level of fixed payment in respect to Insecurity in between male and female is accepted. Here mean of (A1) is little bit higher than mean of (A2). SD value of A1 is 2.68 and A2 is 2.76 and the value of $\mathrm{df}$ is 49 .

Chat No 1.1.7: Showing the mean difference in fixed payment in respect to Insecurity.

(C) www.ijip.in 


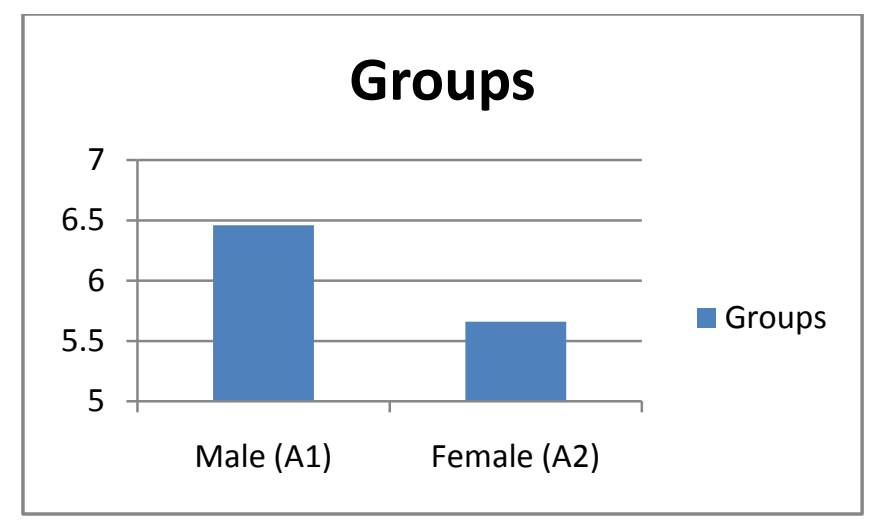

\section{INSECURITY}

Table no 2.1: Showing the result of mean difference in permanent payment in respect to Emotional un-stability.

\section{B1-B2 1}

\begin{tabular}{|c|c|c|}
\hline 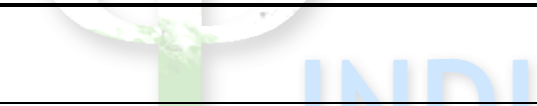 & $\begin{array}{l}\text { Variable } \\
1\end{array}$ & $\begin{array}{l}\text { Variable } \\
2\end{array}$ \\
\hline Mean & 19.88 & 20.86 \\
\hline Variance & 25.65878 & 32.16367 \\
\hline Observations & 50 & 50 \\
\hline Pearson Correlation & -0.10787 & \\
\hline Hypothesized Mean Difference & 0 & \\
\hline df & 49 & \\
\hline t Stat & -0.86607 & \\
\hline $\mathrm{P}(\mathrm{T}<=\mathrm{t})$ one-tail & 0.195336 & \\
\hline t Critical one-tail & 1.676551 & \\
\hline $\mathrm{P}(\mathrm{T}<=\mathrm{t})$ two-tail & 0.390672 & \\
\hline t Critical two-tail & 2.009575 & \\
\hline
\end{tabular}

Table no 2.1.1: Showing the mean difference in permanent payment in respect to Emotional un-stability.

\begin{tabular}{|l|l|l|l|l|}
\hline Groups & Mean & SD & df & t-value \\
\hline Male (A1) & 19.88 & 5.22 & 49 & -0.86607 \\
\cline { 1 - 4 } Female (A2) & 20.86 & 5.48 & & \\
\hline
\end{tabular}

(c) www.ijip.in 
The $t$ value is -0.86607 . As shown in the table the mean of group's male (A1) is 19.88 and female (A2) are 20.86. There is no significant difference between male and female in Emotional un-stability. Therefore the hypothesis stating "There will be no significant difference in the level of permanent payment in respect to Emotional un-stability in between male and female is accepted. Here mean of (A1) is little bit lower than mean of (A2).

Chat No 2.1.1: Showing the mean difference in permanent payment in respect to Emotional un-stability.

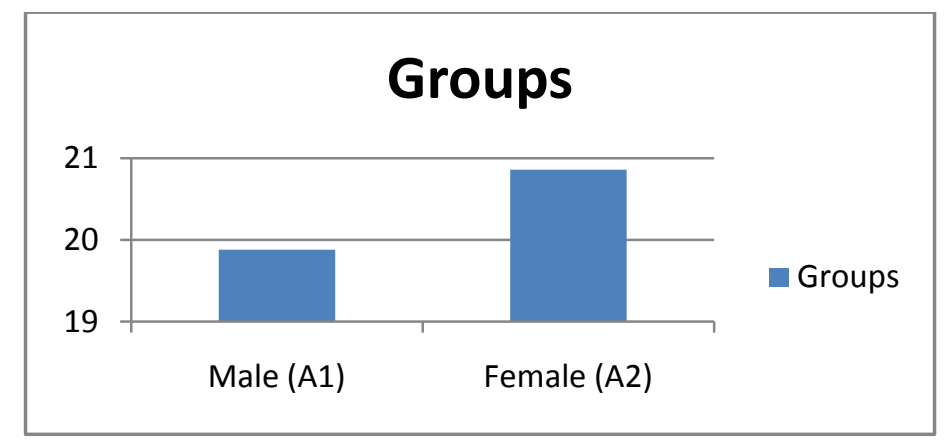

Table no 2.2: Showing the result of mean difference in permanent payment in respect to Emotional regression.

\begin{tabular}{|c|c|c|}
\hline & Variable & Variable \\
\hline Mean & 18.7 & 19.52 \\
\hline Variance & 46.62245 & 59.15265 \\
\hline Observations & 50 & 50 \\
\hline Pearson Correlation & -0.15241 & \\
\hline Hypothesized Mean Difference & 0 & \\
\hline $\mathrm{df}$ & 49 & \\
\hline t Stat & -0.52542 & \\
\hline $\mathrm{P}(\mathrm{T}<=\mathrm{t})$ one-tail & 0.300831 & \\
\hline t Critical one-tail & 1.676551 & \\
\hline $\mathrm{P}(\mathrm{T}<=\mathrm{t})$ two-tail & 0.601662 & \\
\hline t Critical two-tail & 2.009575 & \\
\hline
\end{tabular}

Table no 2.1.2: Showing the mean difference in permanent payment in respect to Emotional regression.

\begin{tabular}{|l|l|l|l|l|}
\hline Groups & Mean & SD & df & t-value \\
\hline Male (A1) & 19.88 & 6.96 & 49 & -0.86607 \\
\cline { 1 - 3 } Female (A2) & 20.86 & 7.75 & & \\
\hline
\end{tabular}

(c) www.ijip.in 
The $t$ value is -0.86607 . As shown in the table the mean of group's male(A1) is 19.88 and female(A2) are 20.86. There is no significant difference between male and female in Emotional regression. Therefore the hypothesis stating "There will be no significant difference in the level of permanent payment in respect to Emotional regression in between male and female is accepted. Here mean of (A1) is little bit higher than mean of (A2).

Chat No 2.1.2: Showing the mean difference in permanent payment in respect to Emotional regression.

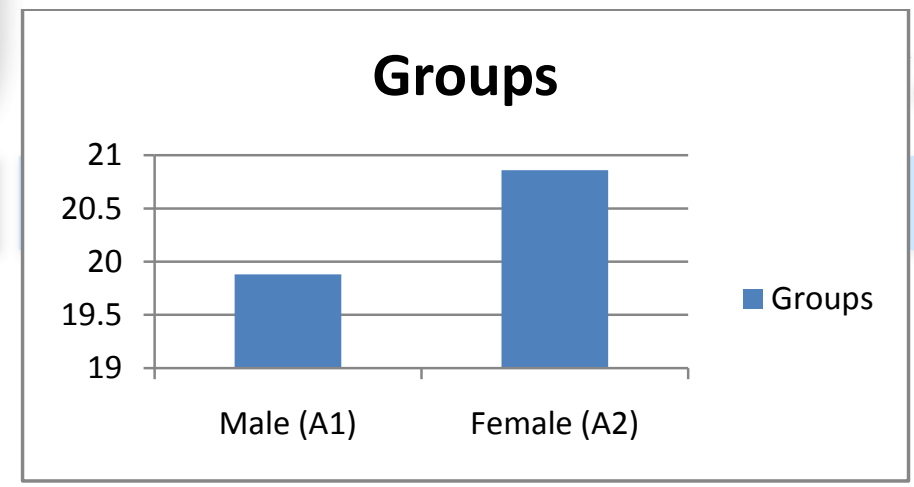

Table no 2.3: Showing the result of mean difference in permanent payment in respect to Social maladjustment.

\begin{tabular}{|l|l|l|}
\hline & & \\
\hline & $\begin{array}{l}\text { Variable } \\
1\end{array}$ & $\begin{array}{l}\text { Variable } \\
2\end{array}$ \\
\hline Mean & 19.52 & 21.26 \\
\hline Variance & 26.98939 & 41.1351 \\
\hline Observations & 50 & 50 \\
\hline Pearson Correlation & -0.01578 & \\
\hline Hypothesized Mean Difference & 0 & \\
\hline df & 49 & \\
\hline
\end{tabular}

(c) www.ijip.in 
The International Journal of Indian Psychology: Volume: 02 | Issue: 02 | February 2014

\begin{tabular}{|l|l|l|}
\hline$t$ Stat & -1.4793 & \\
\hline $\mathrm{P}(\mathrm{T}<=\mathrm{t})$ one-tail & 0.07273 & \\
\hline $\mathrm{t}$ Critical one-tail & 1.676551 & \\
\hline $\mathrm{P}(\mathrm{T}<=\mathrm{t})$ two-tail & 0.14546 & \\
\hline $\mathrm{t}$ Critical two-tail & 2.009575 & \\
\hline
\end{tabular}

Table no 2.1.3: Showing the mean difference in permanent payment in respect to Social maladjustment.

\begin{tabular}{|l|l|l|l|l|}
\hline Groups & Mean & SD & df & t-value \\
\hline Male (A1) & 19.52 & 5.31 & 49 & -1.4793 \\
\cline { 1 - 3 } Female (A2) & 21.26 & 6.50 & & \\
\hline
\end{tabular}

The $t$ value is -1.4793. As shown in the table the mean of group'smale (A1) is 19.52 and female (A2) are 21.26. There is no significant difference between male and female in Emotional regression. Therefore the hypothesis stating "There will be no significant difference in the level of permanent payment in respect to Emotional regression in between male and female is accepted. Here mean of (A1) is little bit lower than mean of (A2).

Chat No 2.1.3: Showing the mean difference in permanent payment in respect to Social maladjustment.

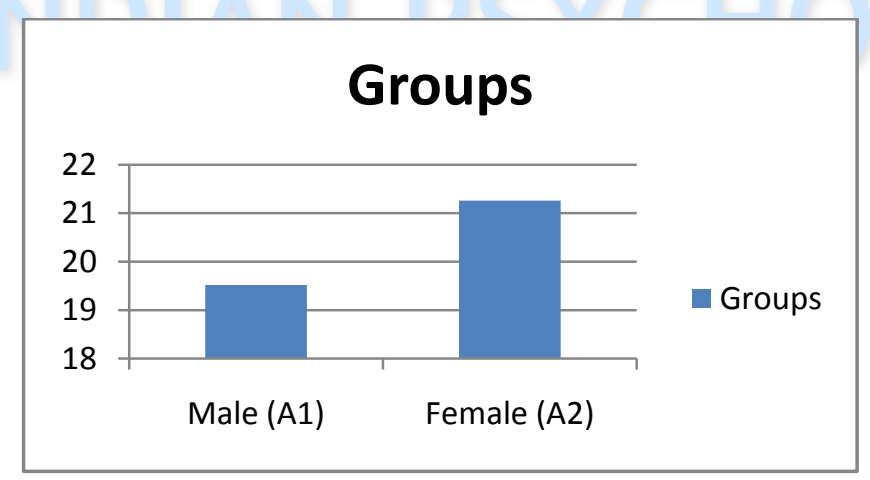

Table no 2.4: Showing the result of mean difference in permanent payment in respect to Personality disintegration.

\begin{tabular}{|l|l|l|}
\hline & & \\
\hline B1-B2 4 & & \\
\hline & & \\
\hline Mean & $\begin{array}{l}\text { Variable } \\
1\end{array}$ & $\begin{array}{l}\text { Variable } \\
2\end{array}$ \\
\hline Variance & 17.34 & 18.6 \\
\hline Observations & 35.90245 & 40.2449 \\
\hline
\end{tabular}

22

(c) www.ijip.in 
The International Journal of Indian Psychology: Volume: 02 | Issue: 02 | February 2014

\begin{tabular}{|l|l|l|}
\hline Pearson Correlation & -0.02749 & \\
\hline Hypothesized Mean Difference & 0 & \\
\hline df & 49 & \\
\hline $\mathrm{t}$ Stat & -1.00728 & \\
\hline $\mathrm{P}(\mathrm{T}<=\mathrm{t})$ one-tail & 0.159375 & \\
\hline $\mathrm{t}$ Critical one-tail & 1.676551 & \\
\hline $\mathrm{P}(\mathrm{T}<=\mathrm{t})$ two-tail & 0.31875 & \\
\hline $\mathrm{t}$ Critical two-tail & 2.009575 & \\
\hline
\end{tabular}

Table no 2.1.4: Showing the mean difference in permanent payment in respect to Personality disintegration.

\begin{tabular}{|l|l|l|l|l|}
\hline Groups & Mean & SD & df & t-value \\
\hline Male (A1) & 17.34 & 6.10 & 49 & -1.00728 \\
\cline { 1 - 3 } Female (A2) & 18.6 & 6.44 & & \\
\hline
\end{tabular}

The $t$ value is -1.00728 . As shown in the table the mean of group'smale (A1) is 17.34 and female (A2) are 18.6. There is no significant difference between male and female in Personality disintegration. Therefore the hypothesis stating "There will be no significant difference in the level of permanent payment in respect to Personality disintegration in between male and female is accepted. Here mean of (A1) is little bit lower than mean of (A2).

Chat No 2.1.4: Showing the mean difference in permanent payment in respect to Personality disintegration.

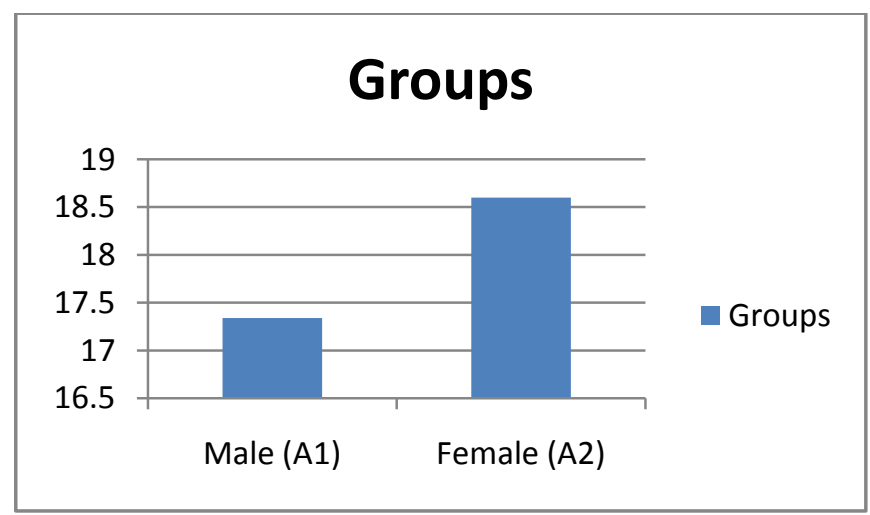

Table no 2.5: Showing the result of mean difference in permanent payment in respect to Lack of independence

\begin{tabular}{|l|l|l|}
\hline B1-B2 5 & & \\
\hline
\end{tabular}

(c) www.ijip.in 


\begin{tabular}{|l|l|l|}
\hline & & \\
\hline & $\begin{array}{l}\text { Variable } \\
1\end{array}$ & $\begin{array}{l}\text { Variable } \\
2\end{array}$ \\
\hline Mean & 16.1 & 17.62 \\
\hline Variance & 24.37755 & 29.7098 \\
\hline Observations & 50 & 50 \\
\hline Pearson Correlation & -0.07136 & \\
\hline Hypothesized Mean Difference & 0 & \\
\hline df & 49 & \\
\hline $\mathrm{t}$ Stat & -1.41216 & \\
\hline $\mathrm{P}(\mathrm{T}<=\mathrm{t})$ one-tail & 0.082111 & \\
\hline $\mathrm{t}$ Critical one-tail & 1.676551 & \\
\hline $\mathrm{P}(\mathrm{T}<=\mathrm{t})$ two-tail & 0.164223 & \\
\hline $\mathrm{t}$ Critical two-tail & 2.009575 & \\
\hline
\end{tabular}

Table no 2.1.5: Showing the mean difference in permanent payment in respect to Lack of independence.

Groups Mean SD df t-value

$\begin{array}{lllll}\text { Male (A1) } & 16.1 & 4.90 & 49 & -1.41216\end{array}$

Female (A2) $\quad 17.62 \quad 5.48$

The $t$ value is -1.41216 . As shown in the table the mean of group's male (A1) is 16.1 and female (A2) are 17.62. There is no significant difference between male and female in Personality disintegration. Therefore the hypothesis stating "There will be no significant difference in the level of permanent payment in respect to Lack of independence in between male and female is accepted. Here mean of (A1) is little bit lower than mean of (A2).

Chat No 2.1.5: Showing the mean difference in permanent payment in respect to Lack of independence.

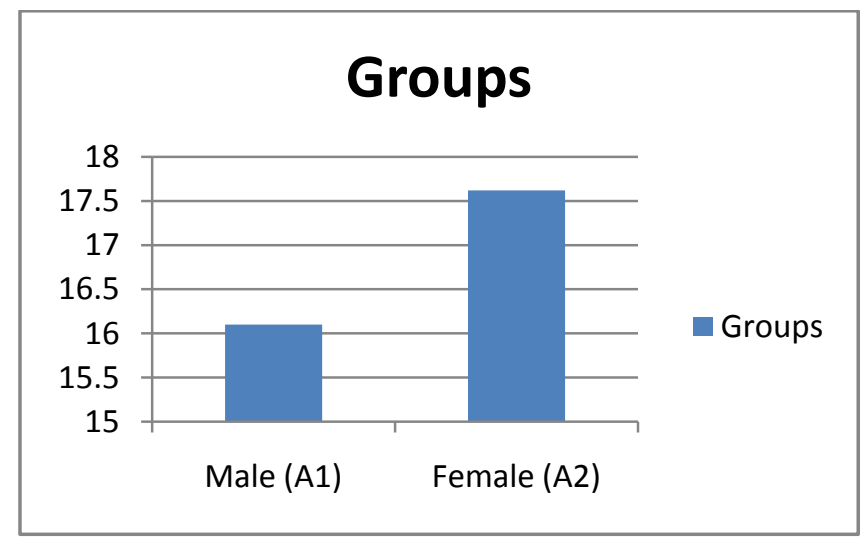

(C) www.ijip.in 
Table no 2.6: Showing the result of mean difference in permanent payment in respect to Emotional maturity.

\begin{tabular}{|l|l|l|}
\hline & & \\
\hline B1-B2 6 & & \\
\hline & & \\
\hline Mean & Variable & Variable \\
& 1 & 2 \\
\hline Variance & 91.54 & 97.64 \\
\hline Observations & 576.131 & 635.582 \\
\hline Pearson Correlation & 50 & 50 \\
\hline Hypothesized Mean Difference & -0.07984 & \\
\hline df & 0 & \\
\hline t Stat & 49 & \\
\hline $\mathrm{P}(\mathrm{T}<=\mathrm{t})$ one-tail & -1.19249 & \\
\hline $\mathrm{t}$ Critical one-tail & 0.119406 & \\
\hline $\mathrm{P}(\mathrm{T}<=\mathrm{t})$ two-tail & 1.676551 & \\
\hline $\mathrm{t}$ Critical two-tail & 0.238812 & \\
\hline
\end{tabular}

Table no 2.1.6: Showing the mean difference in permanent payment in respect to Emotional maturity.

\begin{tabular}{|l|l|l|l|l|}
\hline Groups & Mean & SD & df & t-value \\
\hline Male (A1) & 91.54 & 24.39 & 49 & -1.19249 \\
\cline { 1 - 3 } Female (A2) & 97.64 & 25.36 & & \\
\hline
\end{tabular}

The $t$ value is -1.19249 . As shown in the table the mean of group's male (A1) is 91.54 and female (A2) are 97.64. There is no significant difference between male and female in Personality disintegration. Therefore the hypothesis stating "There will be no significant difference in the level of permanent payment in respect to Emotional maturityin between male and female is accepted. Here mean of (A1) is little bit lower than mean of (A2).

Chat No 2.1.6: Showing the mean difference in permanent payment in respect to Emotional maturity.

(C) www.ijip.in 


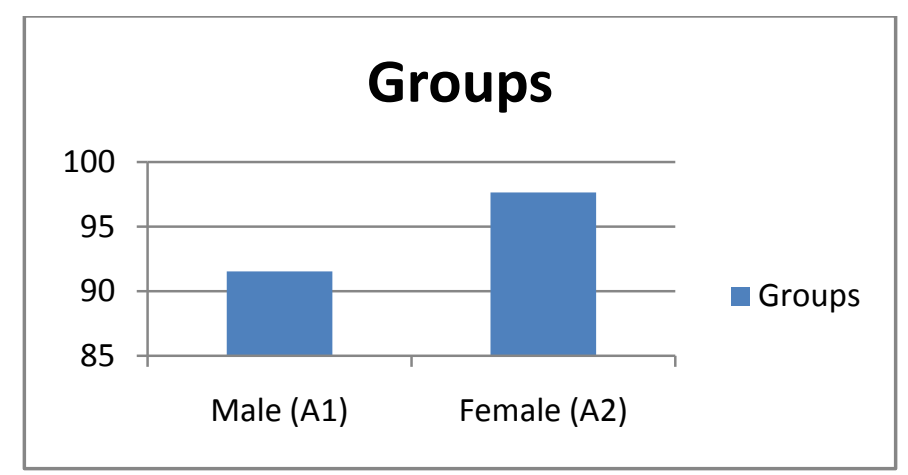

Table no 2.7: Showing the result of mean difference in permanent payment in respect to Insecurity.

\begin{tabular}{|l|l|l|}
\hline & $\begin{array}{l}\text { Variable } \\
1\end{array}$ & $\begin{array}{l}\text { Variable } \\
2\end{array}$ \\
\hline Mean & 6.2 & 5.92 \\
\hline Variance & 9.632653 & 5.340408 \\
\hline Observations & 50 & 50 \\
\hline Pearson Correlation & -0.03187 & \\
\hline Hypothesized Mean Difference & 0 & \\
\hline $\mathrm{df}$ & 49 & \\
\hline $\mathrm{t}$ Stat & 0.504031 & \\
\hline $\mathrm{P}(\mathrm{T}<=\mathrm{t})$ one-tail & 0.308249 & \\
\hline $\mathrm{t}$ Critical one-tail & 1.676551 & \\
\hline $\mathrm{P}(\mathrm{T}<=\mathrm{t})$ two-tail & 0.616498 & \\
\hline $\mathrm{t}$ Critical two-tail & 2.009575 & \\
\hline
\end{tabular}

Table no 2.1.7: Showing the mean difference in permanent payment in respect to Insecurity.

\begin{tabular}{|l|l|l|l|l|}
\hline Groups & Mean & SD & df & t-value \\
\cline { 1 - 3 } Male (A1) & 6.2 & 3.15 & 49 & -0.504031 \\
\cline { 1 - 3 } Female (A2) & 5.92 & 2.37 & & \\
\hline
\end{tabular}

The $t$ value is -0.50431 . As shown in the table the mean of group's male (A1) is 6.2 and female (A2) are 5.92. There is no significant difference between male and female in Personality disintegration. Therefore the hypothesis stating "There will be no significant difference in the

(C) www.ijip.in 
level of permanent payment in respect to Insecurity in between male and female is accepted. Here mean of (A1) is little bit lower than mean of (A2).

Chat No 2.1.7: Showing the mean difference in permanent payment in respect to Emotional maturity.

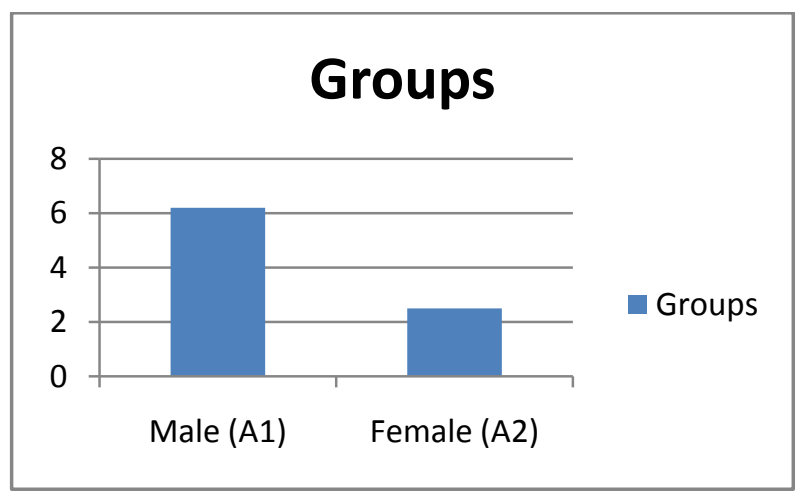

\section{CONCLUSATION:}

- There will be no significant difference between male and female in emotional un-stability.

- There will be no significant difference between male and female in emotional regression.

- There will be no significant difference between male and female in social maladjustment.

- There will be no significant difference between male and female in personality disintegration.

- There will be no significant difference between male and female in independent.

- There will be no significant difference between male and female in insecurity.

- There will be no significant difference between male and female in insecurity un-stability.

- There will be no significant different between male and female in insecurity regression.

- There will be no significant different between male and female in social maladjustment.

- There will be no significant different between male and female in personality disintegration.

- There will be no significant different between male and female in lack of independence. 


\section{SUGGESTIONS:}

Following are some suggestion of vital importance for further research related in this field.

1. The study covered the sample only from Anand district; further research could be conducted on other wider population may provide richer and more valuable information.

2. Further investigation may be undertaken to see the effect of education and personality of subjects.

3. Any other statistical techniques can be also used on the same sample.

\section{Reference:}

1. Allen, J. P., Philliber, S., Herrling, S., \& Kuperminc, G. P. (1997). Preventing teen pregnancy and academic failure: Experimental evaluation of a developmentally based approach. Child Development, 64(4), 729-742.

2. Archibald, A. B., Graber, J. A, \& Brooks-Gunn, J. (1999). Associations among parent adolescent relationships, pubertal growth, dieting, and body image in young adolescent girls: A short-term longitudinal study. Journal of Research on Adolescence, 9, 395-415.

3. Arnett, J. (1999). Adolescent storm and stress, reconsidered. American Psychologist, 54(5), 317-326. Arnett, J., \& Balle-Jensen, L. (1993). Cultural bases of risk behaviour. Child Development, 64, 1842-1855.

4. Aronson, E. (2000). Nobody left to hate: Teaching compassion after Columbine. New York: Freeman.

5. Aronson, E., \& Patnoe, S. (1997). Cooperation in the classroom: The jigsaw method. New York: Longman.

6. Asher, S. R., \& Coie, J. D. (Eds.) (1990). Peer rejection in childhood. New York: Cambridge University Press.

7. Attneave, C. (1982). American Indians and Alaska Native Families: Emigrants in their own homeland. In M.

8. McGoldrick, J. K. Pearce, \& J. Giordano (Eds.), Ethnicity and family therapy. New York: Guilford Press.

9. Bakken, L., \& Romig, C. (1992). Interpersonal needs in middle adolescents: Companionship, leadership, and intimacy. Journal of Adolescence, 15, 301-316.

10. Bagwell, C. L., Newcomb, A. F., \& Bukowski, W. M. (1998). Preadolescent friendship and peer rejection as predictors of adult adjustment. Child Development, 69, 140-153.

11. Balassone, M. L. (1991). A social learning model of adolescent contraceptive behaviour. Journal of Youth and Adolescence, 20, 593-616.

12. Barnes, G. M., Farrell, M. P., \& Banerjee, S. (1995). Family influences on alcohol abuse and other problem behaviours among Black and White Americans. In G. M. Boyd, J.

13. Howard, \& R. A. Zucker (Eds.), Alcohol problems among adolescents. Hillsdale, NJ: Erlbaum.

(C) www.ijip.in 
14. Barnes, G. M., Farrell, M. P., \& Banerjee, S. (1994). Family influences on alcohol abuse and other problem behaviors among Black and White adolescents in a general population sample. Journal of Research in Adolescence, 4, 183-202.

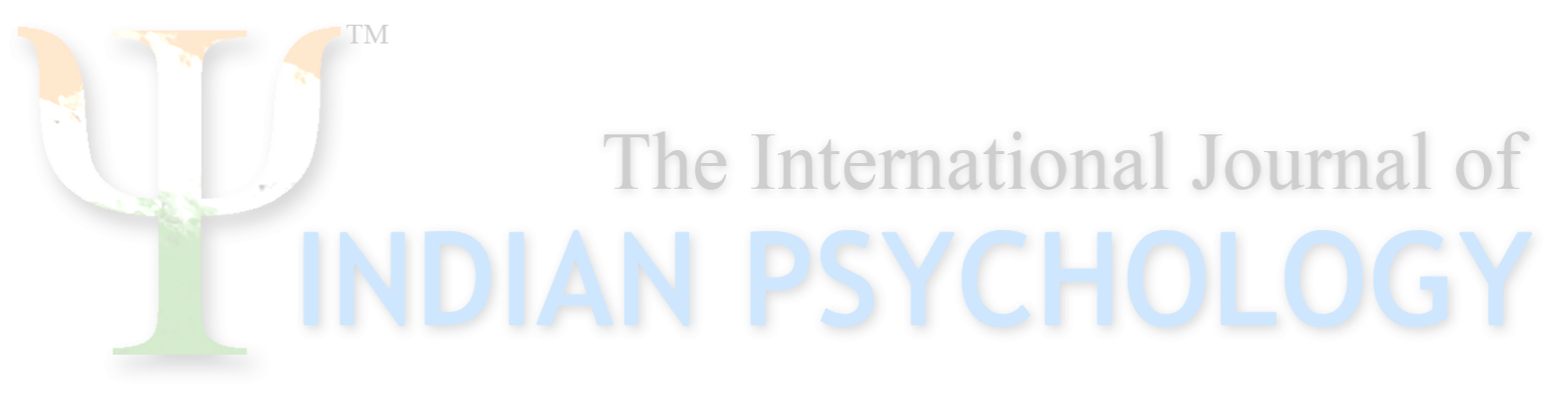

